\title{
Kepastian Hukum Merek Tiga Dimensi dan Desain Industri: Studi Perbandingan Hukum di Indonesia, Amerika dan Australia
}

\author{
Junimart Girsang \\ Florianus Yudhi Priyo Amboro \\ Rina S. Shahrullah \\ Novita \\ Email Korespondensi : rina@ uib.ac.id
}

Fakultas Hukum, Universitas Internasional Batam, Batam, Indonenesia

\begin{abstract}
This research was conducted by adopting a comparative study between Indonesia, USA, and Australia to understand the regulations in each country. The law theory used is Theory of Legal Certainty by Gustav Radburch. This research is a normative law research that used secondary data which consists of the primary, secondary and tertiary legal materials. The data was collected by library research. The secondary data was analysed by using a comparative law method with a descriptive qualitative analysis. The research found that the American law is the most appropriate regulations to govern the three-dimensional shape mark and Industrial Design. It is then followed by Australia and Indonesia. Indonesia may use the American and Australian laws as the best practices to provide the protection of threedimensional shapes.
\end{abstract}

Keywords: Comparative Law, Three Dimensional Marks

\begin{abstract}
ABSTRAK
Penelitian ini dilakukan dengan melakukan studi perbandingan antara Indonesia, Amerika dan Australia yang bertujuan untuk mengetahui pengaturan hukum di masing-masing negara. Teori hukum yang dipergunakan adalah Teori Kepastian Hukum menurut Gustav Radburch. Penelitian ini merupakan penelitian hukum normatif yang menggunakan data sekunder yang terdiri atas bahan hukum primer, sekunder dan tersier. Pengumpulan data dilakukan melalui studi kepustakaan. Data sekunder dianalisis menggunakan metode perbandingan hukum dengan analisis kualitatif deskriptif. Berdasarkan penelitian diketahui bahwa Hukum Amerika merupakan pengaturan hukum yang sangat tepat dalam mengatur merek dan desain industri berbentuk tiga dimensi. Selanjutnya diikuti oleh Australia, dan Indonesia. Indonesia dapat menggunakan hukum Amerika dan Australia sebagai contoh baik dalam memberikan kepastian perlindungan bentuk tiga dimensi.
\end{abstract}

Kata Kunci: Merek Tiga Dimensi; Perbandingan Hukum 


\section{Pendahuluan}

Seiring berkembangnya dunia perdagangan global, perdagangan tidak hanya terbatas pada lingkup nasional tetapi juga internasional. Maka perlindungan terhadap merek di Indonesia juga harus mengikuti perkembangan dunia internasional. ${ }^{1}$ Sebagai anggota dari "World Trade Organization (WTO)" Indonesia meratifikasi "The Agreement on TradeRelated Aspects of Intellectual Property Rights" atau yang kita kenal dengan TRIPs Agreement. ${ }^{2}$ Kesepakatan internasional ini mengatur hal-hal terkait hak kekayaan intelektual termasuk tentang merek (trademark). World Intellectual Property Organizations (WIPO) sebagai organisasi internasional di bidang kekayaan intelektual bagi negara-negara anggota TRIPs Agreement, menyediakan forum khusus untuk membahas isu-isu tentang hukum merek, desain industri, dan indikasi geografis internasional. Pada tanggal 13 November 2006 diadakan "Sixteenth Session of Standing Committee on the Law of Trademarks, Industrial Designs and Geographical Indications”. Agenda dari forum ini diantaranya membahas merek non-tradisional ("New Types of Marks" atau Tipe Merek Baru). Salah satu hasil forum tersebut adalah penjabaran kategori merek baru yakni Visible dan Non-Visible (tampak dan tidak tampak). ${ }^{3}$

Tanda Merek yang tergolong Visible yaitu "Three-dimensional marks, Color marks, Holograms, Slogans, Titles of films and books, Motion or Multimedia signs, Position marks dan Gesture marks". Berbeda dengan Merek Non-Visible yaitu "Sound marks, Olfactory marks, Taste marks dan Texture or feel marks." "4 Tipe Merek Baru di atas dapat disebut juga sebagai merek non-tradisional. Konsep merek non-tradisional memiliki contoh antara lain "bau (fragrance), suara (sound), nama domain (domain name), gambar bergerak (moving image), tanda sentuhan (touch marks), bentuk bangunan (building shapes) dan termasuk bentuk tiga dimensi (three-dimensional marks)." ${ }^{, 5}$ Konsep merek non-tradisional berbeda dengan konsep merek tradisional seperti gambar, nama, kata, huruf, angka, dan susunan warna. Indonesia juga memberikan perlindungan terhadap merek non-tradisional, sejauh ini terhadap 3 jenis merek non-tradisional yang dilindungi, yaitu merek tiga dimensi,

\footnotetext{
${ }^{1}$ Prasetya, I. M. D., \& Ariana, I. G. P. (2019). "Pengaturan Merek Produk Makanan (Berdasarkan UndangUndang No. 20 Tahun 2016 Tentang Merek)". Kertha Semaya: Journal Ilmu Hukum, 7(1), 1-14.

${ }^{2}$ Nadeak, N. A., \& Wauran, I. (2019). “Tumpang-Tindih Pengaturan Bentuk Tiga Dimensi Dalam UndangUndang Merek Dan Undang-Undang Desain Industri”. Jurnal Hukum Ius Quia Iustum, 26(1), 21-43.

3 Amrikasari, R. (2019). Dasar Hukum Perlindungan Merek Non-Tradisional, https://www.hukumonline.com/klinik/detail/ulasan/lt5bee57cd0c924/dasar-hukum-perlindungan-merek-nontradisional, Diakses 30 Oktober 2019.

${ }^{4}$ Ibid.

${ }^{5}$ Reidl, P.W. (2019). Understanding Basic Trademark Law : a Primer on Global Trademark Protection, USA: Practising Law Institute.
} 
suara, dan hologram. Pengaturannya dapat dilihat pada Undang-Undang No. 20 Tahun 2016 tentang Merek dan Indikasi Geografis.

Pasal 1 angka 1 UU No. 20 Tahun 2016 berbunyi: "Merek adalah tanda yang dapat ditampilkan secara grafis berupa gambar, logo, nama, kata, huruf, angka, susunan warna, dalam bentuk 2 (dua) dimensi dan/ atau 3 (tiga) dimensi, suara, hologram, atau kombinasi dari 2 (dua) atau lebih unsur tersebut untuk membedakan barang dan/atau jasa yang diproduksi oleh orang atau badan hukum dalam kegiatan perdagangan barang dan/atau jasa.

Perlindungan terhadap jenis-jenis Merek dalam UU No. 20 Tahun 2016 mengalami perkembangan dibandingkan Undang-Undang Merek sebelumnya UU No. 15 Tahun 2001 yang menyatakan: "Merek adalah tanda yang berupa gambar, nama, kata, huruf-huruf, angkaangka, susunan warna, atau kombinasi dari unsur-unsur tersebut yang memiliki daya pembeda dan digunakan dalam kegiatan perdagangan barang atau jasa."

Dilindunginya bentuk tiga dimensi sebagai merek, mengakibatkan ada dua UndangUndang yang mengatur dan memberikan perlindungan terhadap bentuk tiga dimensi, yaitu Undang-Undang Desain Industri dan Undang-Undang Merek. Sebelum Undang-Undang Merek Tahun 2016 disahkan, telah berlaku Undang-Undang No. 31 Tahun 2000 tentang Desain Industri yang mengatur mengenai perlindungan terhadap bentuk tiga dimensi yang dapat digunakan untuk menghasilkan suatu produk, barang, komoditas industri, atau kerajinan tangan. Terdapat dua undang-undang yang memberikan perlindungan terhadap bentuk tiga dimensi berpotensi terjadinya tumpang tindih pengaturan terhadap bentuk tiga dimensi. Untuk itu, dipandang perlu penelitian perbandingan hukum mengenai kepastian pengaturan hukum merek tiga dimensi dan desain industri di Indonesia, Amerika, dan Australia. Melalui perbandingan hukum tersebut, penelitian ini bertujuan agar Indonesia dapat mengadaptasi pengaturan hukum Amerika dan Australia yang mengatur Merek Tiga Dimensi tidak dapat didaftarkan mengingat bahwa baik Amerika, Australia dan Indonesia mempunyai kesamaan karena ketiga negara tersebut secara eksplisit tidak mengatur larangan untuk mendaftarkan bentuk tiga dimensi melalui Undang-Undang Merek dan Undang-Undang Desain Industri/Paten.

\section{Metode Penelitian}

Guna menjawab rumusan masalah dalam penelitian ini maka Penulis menggunakan jenis penelitian hukum normatif yang difokuskan ke penelitian perbandingan hukum. Penelitian perbandingan hukum adalah penelitian yang mengamati dua atau lebih jenis peraturan perundang-undangan yang mengatur hal yang sama. Penelitian ini menelusuri dan menginventarisasi apa perbedaan serta apa persamaan regulasi yang dibandingkan, disamping 
itu juga mengamati latar belakang adanya persamaan dan latar belakang perbedaannya. ${ }^{6}$ Data yang dipergunakan oleh Penulis adalah data sekunder yang diperoleh dari bahan-bahan pustaka. Pada penelitian hukum, data sekunder mencakup bahan hukum primer, bahan hukum sekunder dan bahan hukum tertier. ${ }^{7}$ Bahan hukum primer berupa peraturan Perundangundangan yang tata urutannya sesuai dengan tata cara pembentukan peraturan perundangundangan yang berlaku ( hukum positif ), antara lain :

a. The Agreement on Trade-Related Aspects of Intellectual Property Rights (TRIPs)

b. Lahnam Act (the U.S. Trademark Act) 1946

c. Consolidated Patent Laws "United States Code Title 35 - Patents"

d. Australian Trade Marks Act 1995

e. Australian Design Act 2003

f. Undang-Undang Dasar Negara Republik Indonesia 1945

g. Undang-Undang No. 31 Tahun 2000 tentang Desain Industri

h. Undang-Undang Nomor 20 Tahun 2016 tentang Merek dan Indikasi Geografis

Bahan Hukum Sekunder berupa bahan hukum yang meliputi fakta hukum, doktrin, asas-asas hukum dan pendapat hukum dalam literatur, jurnal, hasil penelitian, dokumen, internet, dan majalah ilmiah yang terkait dengan obyek yang diteliti. Bahan Hukum Tersier berupa kamus-kamus tentang bahasa umum dan bahasa Indonesia, kamus pembahasan hukum, serta kamus Inggris-Indonesia yang digunakan untuk melengkapi analisis bahan hukum primer dan bahan hukum sekunder.

\section{Analisis dan Pembahasan}

\section{Perbandingan Pengaturan Hukum Mengenai Merek Tiga Dimensi dan Desain Industri di Indonesia, Amerika, dan Australia}

Indonesia, Amerika, dan Australia merupakan anggota World Trade Organization (WTO) yang telah meratifikasi TRIPs Agreement. Dalam TRIPs Agreement tertuang pengaturan terhadap Merek pada Article 15 dan Desain Industri pada Article 25. Hukum Positif di Indonesia, Amerika, dan Australia juga mengatur mengenai perlindungan terhadap Kekayaan Intelektual (Intellectual Property) Merek dan Desain Industri. Di Indonesia, perlindungan merek tiga dimensi tertuang dalam Undang-Undang No. 20 Tahun 2016. Pasal 1 angka 1 UU Merek tahun 2016, berbunyi "Merek adalah tanda yang dapat

\footnotetext{
${ }^{6}$ Nawi, S. (2018). Penelitian Hukum Normatif Versus Penelitian Hukum Empiris, Makassar: PT Umitoha Ukhuwah Grafika.

${ }^{7}$ Benuf, K., \& Azhar, M. (2020). "Metodologi Penelitian Hukum sebagai Instrumen Mengurai Permasalahan Hukum Kontemporer”. Gema Keadilan, 7(1), 20-33.
} 
ditampilkan secara grafis berupa gambar, logo, nama, kata, huruf, angka, susunan warna, dalam bentuk 2 (dua) dimensi dan/atau 3 (tiga) dimensi, suara, hologram, atau kombinasi dari 2 (dua) atau lebih unsur tersebut untuk membedakan barang dan/atau jasa yang diproduksi oleh orang atau badan hukum dalam kegiatan perdagangan barang dan/atau jasa."

Pasal 2 ayat 3 Undang-Undang Merek No. 20 Tahun 2016 mempertegas perlindungan merek tiga dimensi, yang berbunyi "Merek yang dilindungi terdiri atas tanda berupa gambar, logo, nama, kata, huruf, angka, susunan warna, dalam bentuk 2 (dua) dimensi dan/atau 3 (tiga) dimensi, suara, hologram, atau kombinasi dari 2 (dua) atau lebih unsur tersebut untuk membedakan barang dan/atau jasa yang diproduksi oleh orang atau badan hukum dalam kegiatan perdagangan barang dan/atau jasa.”

Perlindungan hukum terhadap Desain Industri di Indonesia tertuang dalam UndangUndang No 31 Tahun 2000 tentang Desain Industri. Pengertian Desain Industri tertuang dalam Pasal 1 Angka 1 yang berbunyi "Desain Industri adalah suatu kreasi tentang bentuk, konfigurasi, atau komposisi garis atau warna, atau garis dan warna, atau gabungan daripadanya yang berbentuk tiga dimensi atau dua dimensi yang memberikan kesan estetis dan dapat diwujudkan dalam pola tiga dimensi atau dua dimensi serta dapat dipakai untuk menghasilkan suatu produk, barang, komoditas industri, atau kerajinan tangan.”

Di Amerika, Merek Tiga Dimensi dikenal juga dengan istilah Trade Dress dan dilindungi dalam Lanham Act pada section 43(a) 15 U.S.C $\$ 1125$ yang berbunyi: "Setiap orang yang berkaitan dengan barang atau jasa, atau kemasan suatu produk, digunakan dalam perdagangan setiap kata, istilah, nama, simbol atau desain atau kombinasi daripadanya, atau setiap penunjukan asal usul palsu, deskripsi fakta yang menyesatkan atau salah, atau representasi fakta yang salah atau menyesatkan, yang berkemungkinan menimbulkan kebingungan, atau menyebabkan kesalahan, atau menipu untuk afiliasi, relasi, atau asosiasi orang tersebut dengan orang lain, atau mengenai asal usul, sponsor, atau persetujuan atas barang, jasa, atau aktivitas komersial dilakukan oleh orang lain, atau dalam iklan atau promosi komersial, salah mengartikan sifat, karakteristik, kualitas, atau asal geografis barang atau jasa orang lain, jasa, atau kegiatan komersialnya, bertanggung jawab atas tindakan perdata kepada orang yang meyakini bahwa dia kemungkinan akan dirugikan oleh tindakan tersebut."

Perlindungan terhadap Trade Dress juga tertuang dalam 15 U.S.C \$1091 Section 23 of The Lanham Act, yang berbunyi: "Untuk kepentingan pendaftaran di supplemental register (pendaftaran tambahan), sebuah tanda dapat terdiri dari merek dagang, simbol, 
label, kemasan, konfigurasi produk, nama, kata, slogan, frase, nama keluarga, nama geografis, angka, perangkat, barang apapun yang sebagai keseluruhan tidak bersifat fungsional, atau kombinasi dari hal-hal tersebut di atas, namun merek tersebut harus mampu membedakan barang atau jasa pemohon."

Di Amerika, Desain Industri dikenal juga dengan Design Patent dan dilindungi berdasarkan United States Code Title 35 - Patents. Design Patent diatur dalam bagian ke 16 (chapter 16) UU tersebut yang berbunyi: "IN GENERAL.—Whoever invents any new, original, and ornamental design for an article of manufacture may obtain a patent therefor, subject to the conditions and requirements of this title." Maka siapa pun yang menciptakan desain baru, orisinal, dan hiasan untuk barang industri dapat memperoleh paten untuk itu, tergantung pada kondisi dan persyaratan pada bagian ini.

Sebelum diperkenalkannya Trade Mark Act 1995 di Australia, merek dagang berbentuk tidak dapat didaftarkan karena merek dagang dianggap sebagai sesuatu yang terpisah dan terlepas dari barang, suatu material tanda dipergunakan untuk ditempelkan pada barang atau wadahnya. Sejak definisi "sign (tanda)" pada section 6 of the Trade Mark Act 1995 secara khusus menyebutkan "shape (bentuk)" sebagai tanda, tidak ada keraguan bahwa bentuk tiga dimensi sekarang dapat didaftarkan sebagai merek dagang jika memenuhi persyaratan Trade Mark Act 1995.Di Australia perlindungan terhadap desain industri tertuang pada Designs Act 2003. Pengertian Desain tertuang pada pasal 5, yang berbunyi "desain dalam kaitannya dengan suatu produk, berarti penampilan keseluruhan produk yang dihasilkan dari satu atau lebih fitur visual dari produk. Fitur visual yang membentuk desain meliputi bentuk, konfigurasi, pola dan ornamen."

Dari peraturan Merek dan Desain Industri di Indonesia, Amerika dan Australia, dapat dilihat Merek dan Desain Industri salah satu objek perlindungan sama yaitu bentuk tiga dimensi. Apabila tidak diatur dengan pasti akan berpotensi meyebabkan tumpang tindih pengaturan. Pada dasarnya perlindungan terhadap Merek dan Desain Industri memiliki konsep yang berbeda. Merek memberikan perlindungan dengan tujuan bahwa bentuk yang diberikan perlindungan tersebut mampu dibedakan dari produk serupa dan menunjukkan asal barang yang berkaitan dengan kualitas produk itu. Agar suatu merek dapat menjadi terkenal serta mampu mewujudkan jaminan kualitas atau reputasi suatu produk tertentu tidaklah mudah, diperlukan waktu yang tidak sebentar serta biaya yang cukup tinggi. ${ }^{8}$ Hal ini yang dilindungi dengan hak merek karena tidak menutup kemungkinan suatu merek

\footnotetext{
${ }^{8}$ Faradz, H. (2008). “Perlindungan Hak Atas Merek”. Jurnal Dinamika Hukum, 8(1). 
terkenal akan ditiru oleh pihak yang beritikad tidak baik guna membonceng reputasinya. ${ }^{9}$ Agar merek menjadi terkenal dan berharga, pemilik merek sering kali melakukan promosi gencar-gencaran yang memakan biaya tidak sedikit dan waktu yang cukup lama. Oleh karena itu, syarat perlindungan Merek tidak dapat disamakan dengan Desain Industri yang mengharuskan adanya unsur kebaruan (novelty).

Berbeda dengan tujuan perlindungan Merek, Desain Industri bertujuan untuk melindungi suatu desain baru yang dihasilkan melalui proses pemikiran yang mana hasil itu bisa dilihat dalam kesan estetis yang ditampilkan oleh bentuk tersebut. ${ }^{10}$ Dengan kata lain, perlindungan desain industri diberikan sebagai bentuk penghargaan terhadap para desainer atas temuannya yang baru tersebut. ${ }^{11}$

Selain itu, merek terdaftar juga dapat diajukan penghapusan oleh pihak ketiga yang memiliki kepentingan apabila tidak digunakannya merek dalam jangka waktu tertentu dalam kegiatan perdagangan, berbeda dengan desain industri yang tidak mewajibkan adanya penggunaan untuk mendapatkan perlindungan. ${ }^{12}$ Pengaturan perlindungan Merek Tiga Dimensi dan Desain Industri di Indonesia tertuang pada Undang-Undang Nomor 20 Tahun 2016 tentang Merek dan Indikasi Geografis dan Undang-Undang Nomor 31 Tahun 2000 tentang Desain Industri. Syarat utama agar Merek dan Desain Industri agar dapat dilindungi yaitu harus memiliki daya pembeda yang dapat membedakan barang dan/atau jasa yang diproduksi oleh orang atau badan hukum dalam kegiatan perdagangan barang dan/atau jasa. Oleh karena itu, merek tiga dimensi juga dapat didaftarkan jika memiliki daya pembeda seperti merek lainnya. Selain itu, disebutkan bahwa merek tiga dimensi harus dapat ditampilkan secara grafis (Pasal 1) dan ketika pendaftaran harus melampirkan label merek dalam bentuk karakteristik dari Merek tersebut (Pasal 4). Karakteristik dari Merek adalah berupa gambar/lukisan yang dapat dilihat dari depan, samping, atas, dan bawah (Penjelasan Pasal 4). Merek tidak dapat didaftarkan dan ditolak apabila melanggar Pasal 20 dan 21 Undang-Undang Merek.

Berdasarkan Pasal 4 UU Merek tahun 2016, syarat pendaftaran merek tiga dimensi sama dengan pendaftaran merek non-tradisional. Perbedaannya hanya terletak pada label Merek yang dilampirkan. Untuk merek tiga dimensi, label merek yang dilampirkan dalam bentuk karakteristik dari Merek tersebut. (Pasal 4(6) UU No. 20/2016)

\footnotetext{
${ }^{9}$ Maulana, I.B. (1997). Sukses Bisnis Melalui Merek, Paten dan Hak Cipta. Bandung: Citra Aditya Bakti.

${ }^{10}$ Saidin, O.K. (2013). Aspek Hukum Hak Kekayaan Intelektual. Jakarta: PT Raja Grafindo.

${ }^{11}$ Mayana, R.F. (2004). Perlindungan Desain Indsutri dalam Era Perdagangan Bebas. Jakarta: PT Gramedia Widiarsama.

12 Bafadhal, T. (2018). "Perlindungan Hukum terhadap Merek Terkenal di Indonesia". Undang: Jurnal Hukum, 1(1), 21-41.
} 
Menurut pendapat salah satu praktisi Hak Kekayaan Intelektual di Indonesia, Bapak Gunawan Suyomurcito, beliau menjelaskan pada dasarnya konsep merek tiga dimensi adalah sebagai tanda pengenal suatu produk, namun tidak seperti merek yang sifatnya konvensional yaitu sebuah tanda yang dilekatkan sebagai pengenal dari suatu produk, merek tiga dimensi dalam hal adalah tanda yang dilekatkan dalam bentuk dari produknya sehingga produk tersebut dapat dikenali dari bentuk tanda tersebut. ${ }^{13}$

Bapak Gunawan juga mengatakan bahwa kekhasan dari suatu tanda tiga dimensi salah satu caranya dapat dilihat dengan melibatkan konsumen sendiri. Beliau mengambil contoh pengukuran kekhasan botol minuman kaca tradisional Coca-Cola yang sudah bantak dikenal konsumen, Dikatakan bahwa "Kekhasan dari bentuk tiga dimensi tersebut dapat terlihat apabila dalam ruangan gelap seorang konsumen dapat mengidentifikasikan produsen suatu produk dengan hanya memegang botol tersebut. Hal ini dikarenakan botol tersebut memang memiliki ciri khas yang membuat konsumen hanya dengan memegangnya sudah dapat mengidentifikasi produsen produk tersebut. Fungsi sebagai tanda pengenal dalam hal ini sejalan dengan fungsi dari sebuah merek, disinilah salah satu cara melihat kekhasan dari suatu tanda tiga dimensi dalam fungsinya sebagai sebuah merek." 14

Pengaturan dan perlindungan terhadap merk tiga dimensi di Indonesia dapat dikatakan masih baru dibandingkan negara-negara maju lainnya. ${ }^{15}$ Pengaturannya pun belum diatur secara spesifik. Meskipun demikian, telah terdapat merek tiga dimensi yang terdaftar di Indonesia di antaranya adalah coklat Ritter Sport (Ritter GmbH) dan Radiator Grill BMW (Bayerische Motoren Werke Aktiengesellschaft). ${ }^{16}$

Syarat Utama perlindungan Desain Industri haruslah memberikan kesan etetis dan memenuhi unsur kebaruan. Tetapi sangat disayangkan pada Undang-Undang Desain Industri tidak dijabarkan lebih lanjut mengenai pengertian estetis dan bagaimana suatu desain dapat dikategorikan mempunyai kesan estetis. Selanjutnya mengenai unsur kebaruan, desain industri dapat didaftarkan apabila merupakan desain yang baru, dianggap baru apabila pada Tanggal Penerimaan, Desain Industri tersebut tidak sama dengan

\footnotetext{
${ }^{13}$ Lestanto, B.S. (2011). Konsep Perlindungan Merek Tiga Dimensi (Three-Dimensional Marks): Definisi, Perlindungan dan Penerapan Hukum, Depok: Skripsi Universitas Indonesia.

14 Ibid.

15 Mayana, R. F. (2017). "Perlindungan Merek Non Tradisional Untuk Produk Ekonomi Kreatif Berdasarkan Undang-Undang Nomor 20 Tahun 2016 Tentang Merek, Indikasi Geografis dan Perspektif Perbandingan Hukum". Jurnal Bina Mulia Hukum, 2(1), 26-41.

16 Amrikasari, R. (2019). Dasar Hukum Perlindungan Merek Non-Tradisional, Available online from: https://www.hukumonline.com/klinik/detail/ulasan/lt5bee57cd0c924/dasar-hukum-perlindungan-merek-nontradisional [accessed 27 November 2019].
} 
pengungkapan yang telah ada sebelumnya (Pasal 2). Pasal 2 ayat 3 UU Desain Industri: "Pengungkapan sebelumnya, sebagaimana dimaksud dalam ayat (2) adalah pengungkapan Desain Industri sebelum tanggal penerimaan, tanggal prioritas, telah diumumkan atau digunakan di Indonesia atau di luar Indonesia". Kata "tidak sama” pada Pasal 2(2) dapat menimbulkan multi-tafsir, yang pertama menafsirkan Desain Industri dianggap baru apabila tidak sama secara signifikan dari Desain Industri yang telah ada sebelumnya, sedangkan penafsiran kedua adalah Desain Industri dianggap baru apabila ada sedikit perubahan dari Desain Industri yang telah ada sebelumnya.

Di Amerika bentuk tiga dimensi dapat dilindungi berdasarkan Lanham Act. Untuk dapat dilindungi, trade dress harus: “(1) memiliki kekhasan yang melekat (inherently distinctiveness) atau telah memperoleh makna sekunder (secondary meaning) di antara konsumen sebagai identifikasi sumber dan asal produk atau jasa; Dan (2) tidak bersifat fungsional (non-functional)."17

Pendaftaran trade dress bertujuan untuk melindungi konsumen dari rangcangan produk yang bermaksud meniru kemasan atau tampilan produk lain; Untuk mencegah konsumen membeli satu produk dengan pikiran bahwa itu adalah produk lain. ${ }^{18}$ Adapun dari berbagai sengketa dan putusan Pengadilan Amerika Serikat mengenai merek tiga dimensi/trade dress, yang menyatakan bahwa "trade dress tidak hanya berupa kemasan suatu produk/desain produk, tetapi dapat berupa bentuk, warna, dan susunan bahan dari pakaian anak-anak dapat menjadi trade dress yang dapat dilindungi (meskipun, desain pakaian itu sendiri tidak terlindungi), desain sampul majalah, penampilan dan dekorasi rantai restoran bergaya Meksiko, dan metode untuk menampilkan botol anggur di toko anggur."19

Dalam putusan kasus antara Two Pesos Inc vs Taco Cabana Inc, trade dress didefinisikan sebagai berikut : "The 'trade dress' of a product is essentially its total image and overall appearance. It involves the total image of a product and may include features such as size, shape, color or color combinations, texture, graphics, or even particular sales techniques". ${ }^{20}$ Lanham Act section 43(a), menghindari terjadinya persaingan tidak sehat dengan memberikan perlindungan kepada merek dagang tidak terdaftar. Menurut Al-Site

\footnotetext{
${ }^{17}$ Stevens, L., \& Mark, S. (2009). VenderBroek, Protecting and Enforcing Trade Dress, Toronto.

18 Merges, R.P., et.ll. (2007). Intellectual Property in the New Technological Age (4 ${ }^{\text {th }}$ rev. ed), New York: Wolters Kluwer.

${ }^{19}$ Wikipedia. (2009). Available online from: https://en.wikipedia.org/wiki/Trade dress [accessed 27 November 2019].

${ }^{20}$ Pattishall, B.W., \& Hilliard, D.C. (2002). Trademarks and Unfair Competition Fifth Edition, LexiNexis Group.
} 
Corp. v. VSI Intern., Inc., untuk membuktikan pelanggaran trade dress atau persaingan tidak sehat, penggugat harus menunjukkan ${ }^{21}$ : “1) kekhasan yang melekat atau makna sekunder dari trade dress, 2) tidak bersifat fungsional, dan 3) berkemungkinan menimbulkan kebingungan konsumen mengenai asal usul, usaha, atau izinnya karena kesamaan antara trade dress penggugat dan tergugat."

Berdasarkan United States Code Title 35 - Patents di Amerika, suatu penemuan dapat dipatenkan jika memiliki unsur kebaruan (novelty) dan materi pokok yang tidak umum (non-obvious subject matter). Maka suatu penemuan tidak dapat dipatenkan jika : 1) penemuan yang diklaim telah dipatenkan, dijelaskan dalam publikasi tercetak, atau untuk penggunaan umum, dijual, atau sebaliknya tersedia untuk umum sebelum tanggal pendaftaran efektif dari penemuan yang diklaim; atau 2) penemuan yang diklaim telah dijelaskan dalam paten yang dikeluarkan (oleh AS), atau dalam aplikasi untuk paten yang diterbitkan atau dianggap diterbitkan (oleh AS), di mana paten atau aplikasi paten, tergantung pada kasusnya, sebelum tanggal pendaftaran efektif dari penemuan yang diklaim telah didaftarkan atas nama penemu lain dan secara efektif didaftarkan.

Ada beberapa pengecualian untuk larangan pendaftaran paten 1) dan 2) di atas. Khususnya, pengecualian dapat berlaku untuk pengungkapan yang dilakukan 1 tahun atau kurang sebelum tanggal pengajuan efektif dari penemuan yang diklaim, tetapi hanya jika pengungkapan itu dilakukan oleh penemu atau penemu bersama atau oleh orang lain yang memperoleh materi yang diungkapkan dari penemu atau penemu bersama.

Dalam larangan paten 1), terdapat istilah "sebaliknya tersedia untuk umum (otherwise available to the public)" mengacu pada jenis pengungkapan lain dari penemuan yang diklaim seperti, misalnya, presentasi lisan pada pertemuan ilmiah, demonstrasi di pameran dagang, kuliah atau ucapan, pernyataan yang dibuat di acara bincang-bincang radio, video YouTube, atau situs web atau materi online lainnya. Klaim Hak Paten terhadap suatu penemuan dapat tidak dikabulkan, meskipun materi pokok yang ingin dipatenkan tidak secara akurat ditunjukkan oleh penemuan sebelumnya, dan melibatkan satu atau lebih perbedaan atas hal yang hampir serupa yang sudah diketahui, paten akan dapat ditolak jika perbedaannya telah umum. Materi pokok yang ingin dipatenkan harus cukup berbeda dari apa yang telah digunakan atau dijelaskan sebelumnya sehingga dapat dikatakan tidak umum bagi seseorang yang memiliki keterampilan biasa dalam bidang

\footnotetext{
${ }^{21}$ Misterovich, E. (2009). Trade Dress Protection. Available online from: https://revisionlegal.com/trademarklaw/trade-dress-protection/ [accessed 27 November 2019].
} 
teknologi yang terkait dengan penemuan ini. Misalnya, penggantian satu warna dengan yang lain, atau perubahan ukuran, biasanya tidak dapat dipatenkan.

Peraturan di Australia mensyaratkan bahwa seluruh permohonan yang mengklaim bentuk sebagai merek dagang harus menyertakan deskripsi dan representasi yang menunjukkan setiap fitur merek dagang dengan cukup jelas untuk memungkinkan pemeriksaan merek dagang yang tepat. Ini memerlukan beberapa pertimbangan berbeda untuk menunjukan merek dagang ini. Meskipun ini bukan persyaratan mutlak, representasi merek dagang harus, jika dapat dilakukan, dalam bentuk perspektif atau gambar isometrik yang menunjukkan dengan jelas semua fitur merek dagang. Bagian-bagian dari konfigurasi yang diklaim sebagai merek dagang harus ditampilkan dalam garis yang solid, sedangkan bagian yang tidak diklaim, jika ada, harus ditampilkan dalam garis yang putus. Gambar, pemandangan, dan/atau foto merek dagang juga harus disertai dengan deskripsi tertulis merek dagang tersebut. Deskripsi dan representasi gambar dari merek dagang bentuk harus bersama-sama dengan jelas menentukan semua detail yang merupakan merek dagang. Contoh deskriptif yang sesuai untuk menyertai representasi adalah sebagai berikut: 1) Merek dagang terdiri dari bentuk biskuit, seperti yang ditunjukkan pada representasi yang terlampir pada formulir aplikasi; 2) Merek dagang terdiri dari bentuk 3-dimensi ayam jago yang diterapkan pada atap kendaraan, seperti yang ditunjukkan dalam representasi yang dilampirkan pada formulir aplikasi, di mana kendaraan itu sendiri digambarkan sebagai garis putus-putus; 3) Dalam kasus di mana representasi gambar sangat jelas, dan semua fitur merek jelas, deskripsi merek dagang yang lebih singkat mungkin dapat diterima. Sebagai contoh: Merek dagang adalah merek dagang tiga dimensi, seperti yang ditunjukkan dalam representasi yang melekat pada formulir aplikasi.

\section{Bentuk dapat dibedakan (Shapes may be capable of distinguishing)}

Pendaftaran untuk bentuk sebagai merek dagang harus dipertimbangkan dengan kriteria luas yang sama dengan jenis tanda lainnya. Tes normal berlaku dan mencakup apakah bentuk yang diklaim sebagai merek dagang mampu membedakan barang atau jasa dari satu pedagang dari barang atau jasa serupa dari yang lain. ${ }^{22}$

\section{Bentuk yang Umum dalam Perdagangan (Shapes which are common to the trade)}

Bentuk yang lumrah digunakan untuk barang yang dimaksud kemungkinan dibutuhkan secara sah oleh pedagang lain. Karena itu tidak mungkin didaftarkan secara

\footnotetext{
${ }^{22}$ Amirulloh, M., \& Kusmawati, A. P. (2014). "Perlindungan Merek terhadap Framing, Meta tag, dan Deep Linking Berdasarkan UU No. 15 Tahun 2001 tentang Merek dan Perbandingannya dengan Regulasi dan Praktik di Amerika Serikat". Padjadjaran Journal of Law, 1(3).
} 
prima facie. Kesimpulan bahwa sesuatu yang umum untuk perdagangan hanya dapat dicapai setelah riset mengungkapkan bahwa bentuk, atau beberapa variasi kecil itu, biasanya digunakan dalam pasar yang relevan.

Contoh jenis bentuk ini adalah botol anggur standar untuk anggur; toples berbentuk silinder biasa untuk saus; bentuk payung standar untuk payung matahari; bentuk cangkir silinder dengan pegangan standar untuk cangkir kopi dan cokelat berbentuk telur atau kelinci untuk Paskah.

\section{Bentuk dan Fungsionalitas (Shape and Functionality)}

Ada sejumlah masalah yang harus dilihat ketika mempertimbangkan apakah pedagang lain cenderung perlu menggunakan bentuk sehubungan dengan barang/jasa mereka sendiri dan dengan demikian apakah itu disesuaikan untuk membedakan. Yang pertama adalah masalah fungsionalitas.

Jika suatu bentuk memiliki fitur fungsional yang signifikan, ada kemungkinan kuat bahwa pedagang lain akan perlu menggunakan bentuk itu untuk barang yang serupa. Tidak seorang pun yang berhak atas kepemilikan eksklusif terhadap kata, perangkat, simbol atau bentuk tiga dimensi yang umum untuk perdagangan. Salah satu cara untuk menguji ini dari perspektif merek bentuk, adalah dengan mempertimbangkan apakah bentuk tersebut terdiri dari jenis elemen fungsional yang umum digunakan dalam industri yang relevan.

Suatu bentuk dapat dianggap fungsional jika: 1) itu adalah bentuk yang penting untuk penggunaan atau tujuan barang. Misalnya, bentuk gagang dan rakitan pisau untuk gunting, diperlukan untuk fungsi barang tersebut; 2) itu adalah bentuk yang diperlukan untuk mencapai hasil teknis tertentu. Misalnya, bentuk baling-baling pada kipas angin yang akan menciptakan pola aliran udara tertentu; 3) itu adalah bentuk yang memiliki keunggulan teknik, menghasilkan kinerja yang unggul. Misalnya, penemuan baru untuk membuka botol yang lebih mudah digunakan daripada perangkat yang ada; 4) bentuknya dihasilkan dari metode pembuatan yang murah dan sederhana. Misalnya, bentuk diekstrusi atau dipotong sederhana untuk biskuit, seperti cakram atau persegi panjang.

\section{Bentuk dan Estetika (Shapes and Aesthetics)}

Tidak ada alasan untuk menolak suatu bentuk hanya karena bentuknya menarik atau estetis, dan karenanya pedagang lain mungkin ingin menggunakannya. Sebagian besar pedagang akan berharap bahwa merek dagang mereka, baik merek berbentuk atau tidak, menarik bagi konsumen. Tes untuk tanda berbentuk harus sama dengan tes yang 
diterapkan untuk tanda lain - apakah bentuk itu salah satu yang ingin digunakan pedagang lain, dalam kegiatan bisnis mereka yang biasa, tanpa motif yang tidak patut.

Pertanyaan mengenai estetika umumnya hanya relevan jika barang dibuat dengan pertimbangan bahwa ornamen kaca di mana ornamen adalah kegunaan dari barang dan tidak mungkin dilihat oleh pembeli potensial sebagai merek dagang yang menunjukkan asal merek.

\section{Bentuk dan Invensi (Shapes and invention)}

Invensi suatu bentuk harus diperlakukan dengan cara yang serupa dengan invensi kata, dan sama-sama berhak atas penerimaan prima facie. Titik awal untuk semua merek dagang termasuk merek dagang "bentuk" adalah pertanyaan "apa yang umum dalam perdagangan"? Ini dapat dinilai melalui penelitian bentuk yang diterapkan dalam perdagangan yang relevan. Jika penelitian menunjukkan sejumlah pihak yang menggunakan bentuk tidak merasa sebagai merek dagang, ini akan cenderung mendukung pandangan bahwa pasar keberatan dan tidak menganggapnya sebagai merek dagang.

Mungkin sulit untuk "menginvensi" bentuk dalam beberapa perdagangan. Sebagai contoh, kategori mainan di kelas 28 sudah memasukkan berbagai macam bentuk sebagai bentuk umum. Dalam kelas ini, tidak mungkin bentuk sederhana seperti beruang atau traktor akan dapat didaftarkan kecuali ada peningkatan tambahan yang cukup besar dari jenis yang biasanya tidak ditemukan di pasar. Pakaian boneka beruang atau boneka tidak akan cukup untuk mengidentifikasi bentuk yang bisa didaftarkan. ${ }^{23}$

Dalam nada yang sama, bentuk barang-barang dekoratif seperti ornamen atau perhiasan tidak akan mungkin menjadi prima facie yang dapat diterima, karena wajar dalam perdagangan ini untuk menyediakan kreasi yang tidak biasa dan imajinatif. Pemohon harus dapat menunjukkan bahwa ia menggunakan bentuk dalam arti merek dagang, tidak hanya memproduksi benda dalam bentuk itu, sebelum pendaftaran merek dapat diterima.

\section{Menyelidiki Merek Berbentuk untuk Pasal 41 (Researching shape marks for section 41)}

Meneliti bentuk-bentuk merek dagang kadang-kadang, dapat menimbulkan masalah bagi penguji. Mungkin sulit untuk menargetkan pencarian ke bentuk itu sendiri, dan metodologi yang paling tepat mungkin untuk mencari situs dalam industri tertentu untuk menentukan bentuk apa yang sudah digunakan. Majalah perdagangan, katalog, brosur iklan, dan publikasi khusus industri, jika tersedia, juga akan bermanfaat.

\footnotetext{
${ }^{23}$ Desmayanti, R. (2018). “Tinjauan Umum Perlindungan Merek Terkenal Sebagai Daya Pembeda Menurut Prespektif Hukum Di Indonesia”. Jurnal Cahaya Keadilan, 6(1), 1-21.
} 
Penting bahwa pemeriksa melihat tidak hanya untuk bentuk yang persis, tetapi untuk bentuk yang serupa dan bentuk di kelas atau kategori yang sama dengan yang diterapkan dalam aplikasi yang sedang dipertimbangkan. Jika bentuknya merupakan variasi kecil dari sesuatu yang sudah umum dalam industri, penguji perlu mengajukan alasan penolakan berdasarkan kurangnya (inherent adaptation to distinguish) adaptasi yang melekat pada bentuk untuk membedakan barang yang diklaim.

8. Bentuk Kemasan atau Aspek dari Kemasan (Shape of packaging or aspect of packaging)

Pertimbangan yang sama untuk fungsi dan kemampuan untuk membedakan yang berlaku untuk bentuk atau konfigurasi barang itu sendiri juga berlaku untuk bentuk atau konfigurasi pengemasan barang. Kemasan mungkin termasuk wadah di mana barang dijual atau kemasan luar yang menutupi barang dan wadah. Bentuk hanyalah salah satu aspek dari pengemasan dan semakin tidak biasa bentuk wadah atau kotak yang digunakan sebagai merek dagang, semakin besar kemungkinan untuk dapat membedakan barang pemohon. Namun, saat ini ada banyak cara penataan dan penyajian wadah dan kemasan yang berbeda sehingga sebagian besar variasi yang biasa tidak akan memenuhi persyaratan pendaftaran.

\section{Bukti Menggunakan untuk Merek Berbentuk (Evidence of use for shape trade marks)}

Jika alasan penolakan diajukan terhadap bentuk merek dagang berdasarkan ketentuan pasal 41 pemohon dapat memutuskan untuk memberikan bukti penggunaan. Setiap bukti semacam itu perlu memenuhi persyaratan dasar yang sama dengan bukti untuk jenis merek dagang lainnya.

Pendaftaran untuk bentuk mungkin menghadapi kesulitan dalam menunjukkan (adaptation to distinguish) adaptasi untuk membedakan. Semua barang memiliki bentuk, dan wadah untuk barang datang dalam bentuk. Pelanggan juga mengharapkan berbagai bentuk barang dalam banyak perdagangan. Jika merek dagang terdiri dari salah satu dari bentuk-bentuk ini, atau variasi kecil pada mereka, tidak mungkin mudah bagi pemohon untuk meyakinkan pencatat bahwa bentuk yang digunakan untuk itu, atau akan dapat melakukan fungsi sebagai merek dagang. ${ }^{24}$

\footnotetext{
${ }^{24}$ Mastuti, S. (2018). "Efektivitas Prinsip Trade Related Aspects Of Intellectual Property Rights Dan Agreement Technical Barriers To Trade Dalam Pemberian Perlindungan Hukum Terhadap Produk Rokok Indonesia Di Australia Atas Pelaksanaan Asas Ketertiban Umum". Selisik: Jurnal Hukum dan Bisnis, 4(2), 42-63.
} 
Agar suatu bentuk mendapat pengakuan sebagai merek dagang, maka harus dipromosikan sebagai sesuatu yang terpisah dari barang. ${ }^{25}$ Masuk dalam katalog atau brosur yang menampilkan gambar barang dalam bentuk yang diklaim tidak menetukan, bahkan jika pemohon mampu menunjukkan materi tersebut selama bertahun-tahun. Agar lebih berpengaruh, penggunaan harus menunjukkan contoh bagaimana pemohon telah merujuk, mempromosikan atau menunjukkan kepada pembeli potensial bahwa bentuk yang diklaim dimaksudkan memiliki fungsi merek dagang. Yang mungkin lebih bermanfaat adalah contoh teks iklan yang secara khusus merujuk pada bentuk sehubungan dengan barang dengan cara yang akan mengarahkan pemeriksa untuk menyimpulkan bahwa bentuk itu tidak hanya tidak biasa dan berbeda dari yang lain yang tersedia di pasar tertentu, tetapi juga dipromosikan sebagai merek.

Pernyataan seperti "Cari kotak berbentuk bintang" atau "Warna menarik; bentuk tidak biasa" adalah jenis promosi yang dapat membantu pemohon dalam menunjukkan bahwa bentuk memiliki kemampuan untuk membedakan.

\section{Desain terdaftar sebagai merek dagang (Registered design as a trade mark)}

Seharusnya tidak ada alasan untuk menolak pendaftaran merek dagang yang atau mengandung bentuk (yaitu, objek tiga dimensi) hanya dengan alasan bahwa pemohon memiliki pendaftaran desain, atau aplikasi yang tertunda untuk pendaftaran sebuah desain, untuk objek tiga dimensi yang sama. Namun, fakta bahwa fitur bentuk dan konfigurasi wadah untuk barang telah terdaftar di bawah Undang-Undang Desain, tidak berarti bahwa mereka semestinya (adapted to distinguish) membedakan sebagai merek dagang. Tes biasa untuk kapasitas untuk membedakan akan berlaku untuk aplikasi ini seperti yang lainnya.

11. Desain Industri harus baru (new) dan khas (distinctive) untuk di daftarkan dapat dilindungi secara hukum. (Pasal 15 Designs Act 2003)

Baru - tidak boleh identik dengan desain apa pun yang sebelumnya diungkapkan di mana pun di dunia. Termasuk apa pun yang diterbitkan di mana saja di dunia atau digunakan secara publik di Australia. Khas - tidak boleh secara substansial serupa dalam kesan keseluruhan dengan desain apa pun yang sebelumnya diungkapkan di mana pun di dunia. Ini juga termasuk apa pun yang diterbitkan di mana saja di dunia atau digunakan secara publik di Australia. Berdasarkan pengaturan syarat Merek dan Desain Industri Tiga Dimensi agar dapat dilindungi di Indonesia, Amerika, dan Australia. Dapat disimpulkan bahwa pengaturan hukum yang paling baik, adalah Negara Amerika, kemudian Negara

\footnotetext{
${ }^{25}$ Disemadi, H. S., \& Mustamin, W. (2020). "Pembajakan Merek Dalam Tatanan Hukum Kekayaan Intelektual Di Indonesia”. Jurnal Komunikasi Hukum (JKH), 6(1), 83-94.
} 
Australia, dan yang terakhir Negara Indonesia. Dikarenakan, Pengaturan Merek Tiga Dimensi dan Desain Industri di Amerika diatur dengan rinci yang meminimalisir terjadinya multitafsir sehingga dapat mencegah terjadinya tumpang tindih perlindungan bentuk tiga dimensi, dibandingkan dengan Indonesia yang mengatur perlindungan Merek dan Desain Industri hanya secara umum sehingga dapat menimbulkan multifsir yang menyebabkan tidak tercapainya kepastian hukum.

Tolak ukur kepastian hukum ini merujuk pada Teori Kepastian Hukum menurut Gustav Radburch yang berbunyi: "Hukum di negara berkembang ada dua pengertian tentang kepastian hukum menurut Gustav Radburch yaitu kepastian oleh karena hukum, dan kepastian dalam atau dari hukum. Menjamin kepastian oleh karena hukum menjadi tugas dari hukum. Hukum yang berhasil menjamin banyak kepastian dalam hubunganhubungan kemasyarakatan adalah hukum yang berguna. Sedangkan kepastian dalam atau dari hukum tercapai apabila hukum itu sebanyak-banyaknya hukum undang-undang, dalam undang-undang tersebut tidak ada ketentuan yang saling bertentangan (Undang-undang berdasarkan pada sistem logis dan pasti). Undang-undang tersebut dibuat berdasarkan kenyataan hukum (rechtswerkelijheid) dan undang-undang tersebut tidak ada istilah-istilah hukum yang dapat ditafsirkan secara berlain-lainan." 26

Salah satu tujuan dibentuknya hukum adalah untuk menciptakan kepastian. Kepastian hukum dapat dicapai apabila terdapat banyak peraturan perundang-undangan tidak ada ketentuan yang saling bertentangan antara undang-undang yang satu dengan yang lain serta tidak terdapat ketentuan yang multi-tafsir. Berdasarkan studi perbandingan yang dilakukan, dapat dikatakan pengaturan hukum mengenai merek dan desain industri di Amerika dan Australia lebih menciptakan kepastian hukum bagi pemilik bentuk tiga dimensi. Pengaturan hukum di Amerika dan Australia tertuang jelas dalam hukum tertulis maupun yurisprudensi negaranya dan minimnya pengaturan yang saling bertentangan maupun multi-tafsir. Berbeda dengan Indonesia yang tergolong baru dalam melindungi bentuk tiga dimensi sebagai merek, sehingga terdapat dua peraturan hukum yang memberikan perlindungan terhadap bentuk tiga dimensi, merek dan desain industri. Perlindungan bentuk tiga dimensi sebagai merek tidak diatur secara rinci dalam undangundang merek maupun desain industri, sehingga menimbulkan penafsiran berbeda-beda dari berbagai pihak yang menyebabkan tidak tercapainya tujuan hukum untuk menciptakan kepastian.

\footnotetext{
${ }^{26}$ Utrecht, E. (1959). Pengantar dalam Hukum Indonesia, Cetakan keenam, Jakarta: PT.Penerbit Balai Buku Ichtiar.
} 
Jangka Waktu Perlindungan Merek dan Desain Industri, secara garis besar Negara Indonesia, Amerika, dan Australia memiliki konsep jangka waktu perlindungan yang sama, yaitu jangka waktu perlindungan merek yang dapat diperpanjang secara berkala apabila tidak bertentangan dengan undang-undang dan jangka waktu perlindungan desain industri yang terbatas pada jangka waktu tertentu dan tidak dapat diperpanjang lagi. Perbedaannya hanya terletak pada janga waktu perlindungan. ${ }^{27}$

Pertama, perbedaan pada jangka waktu perlindungan. Undang-Undang Merek memberikan perlindungan merek selama 10 tahun dan dapat diperpanjang dalam jangka waktu yang sama, yaitu 10 Tahun (Pasal 35). Dalam Undang-Undang tersebut tidak disebutkan pembatasan berapa kali perpanjangan merek dapat dilakukan, sehingga dapat ditafsir bahwa merek dapat diperpanjang berulang-ulang kali setiap 10 tahun sekali selama mematuhi peraturan yang berlaku. Berbeda dengan jangka waktu perlindungan Desain Industri, Undang-Undang Desain Industri memberikan jangka waktu perlindungan selama 10 Tahun (Pasal 5) dan dalam Undang-Undang tersebut tidak disebutkan mengenai perpanjangan jangka waktu perlindungan desain industri, sehingga dapat ditafsir bahwa perlindungan terhadap desain industri tidak dapat diperpanjang dan apabila telah melewati waktu 10 Tahun maka desain industri akan menjadi milik umum dan pihak lain dapat menggunakan desain tanpa izin dari pemilik desain.

Berdasarkan 15 U.S.C $\$ 1059$ Lanham Act, Jangka waktu perlindungan terhadap merek adalah 10 tahun, dengan masa perpanjangan 10 tahun. Sedangkan Design Patent yang diterbitkan sebelum 13 Mei 2015 memiliki jangka waktu perlindungan selama 14 tahun sejak dikabulkan. Design Patent yang didaftarkan setelah 13 Mei 2015, jangka waktu paten telah direvisi menjadi 15 tahun sejak tanggal pemberian paten untuk paten desain yang dikeluarkan dari kedua aplikasi desain nasional di bawah Bab 16 dan aplikasi desain internasional yang menunjuk ke Amerika Serikat. (35 U.S.C. 173)

Di Australia jangka waktu perlindungan merek tiga dimensi dan desain industri yaitu, merek tiga dimensi selama 10 tahun, kecuali jika sebelumnya telah dibatalkan, atau merek dagang sebelumnya dihapus dari Register. Pendaftaran merek dagang dapat diperbarui untuk 10 tahun kedepan jika diajukan dalam waktu 6 bulan setelah pendaftaran merek dagang telah berakhir. Desain industri dilindungi selama 5 Tahun sejak tanggal pengajuan aplikasi desain dan dapat diajukan perpanjangan perlindungan satu kali selama 5 Tahun. Jadi jangka waktu perlindungan desain industri di Australia maksimal 10 Tahun.

\footnotetext{
${ }^{27}$ Rahmawati, D. (2016). Perlindungan Hukum Atas Indikasi Geografis (Studi Perbandingan Hukum Indonesia Dengan Australia). Kumpulan Jurnal Mahasiswa Fakultas Hukum.
} 
Amerika, Australia, dan Indonesia merupakan anggota World Intellectual Property Organization atau WIPO. Standing Committee On The Law Of Trademarks, Industrial Design And Geographical Indications menerbitkan Ninth Session tanggal November 11 to 15, 2002 mengenai “Industrial Designs And Their Relation With Works Of Applied Art And Three-Dimensional Marks (Desain Industri serta hubungannya dengan Karya Cipta dan Merek Tiga Dimensi)". Dokumen tersebut mengatakan bahwa Desain Industri dan Merek memiliki peran yang berbeda dalam perekonomian, dan memiliki alasan yang berbeda dilindungi sebagai kekayaan intelektual. Meskipun salah satu objek perlindungan Merek dan Desain Industri sama, yaitu bentuk tiga dimensi.

Pengakuan dan perlindungan Merek terhadap tanda apa pun tergantung pada persyaratan mendasar bahwa tanda tersebut dapat dibedakan, yaitu mampu membedakan barang atau jasa yang berlaku. Agar suatu tanda "berbeda", ia harus menyampaikan (paling tidak kepada konsumen yang dituju) gagasan bahwa produk (atau jasa) yang memuat tanda itu telah diletakkan di pasar oleh, atau di bawah wewenang, suatu entitas komersial tertentu. Suatu merek harus mampu menunjukkan kepada publik bahwa semua produk yang dibedakan oleh merek tersebut memiliki asal komersial atau sponsor. Kondisi ini harus dipenuhi juga oleh merek tiga dimensi, jika mereka ingin mendapat manfaat dari perlindungan sebagai merek. ${ }^{28}$

Fungsi desain industri adalah untuk membuat produk lebih menarik bagi mata, yaitu, lebih menarik secara estetis bagi calon pembeli. Keindahan tampilan tidak hanya menambah nilai estetika tetapi juga nilai komersial untuk produk apa pun. Nilai itu menjadi nyata ketika sebuah produk, misalnya arloji, mewujudkan desain tertentu dapat menuntut harga pasar yang lebih tinggi daripada arloji identik fungsional yang memiliki bentuk atau aspek yang berbeda. ${ }^{29}$

Tidak seperti hak desain industri yang jangka waktu perlindungannya terbatas, hak merek dapat diperpanjang tanpa batas waktu, melalui penggunaan berkelanjutan untuk membedakan barang atau jasa di pasar, dan pembaruan berkala pendaftaran merek. Namun, hak eksklusif yang abadi dalam merek tidak akan merugikan persaingan, karena tidak perlu mendompleng atau menggunakan merek orang lain untuk dapat memproduksi dan menjual barang yang sama secara kompetitif.

\footnotetext{
${ }^{28}$ Standing Committee On The Law Of Trademarks, Industrial Design And Geographical Indications. (2002) Industrial Designs And Their Relation With Works Of Applied Art And Three-Dimensional Marks, Geneva. ${ }^{29}$ Ibid.
} 
Meskipun bentuk atau konfigurasi produk tertentu pada awalnya dimaksudkan sebagai desain industri, ia kemudian dipertahankan dan dikembangkan menjadi merek untuk produk tersebut. Dalam hal ini, bentuk atau konfigurasi akan menikmati perlindungan kumulatif di bawah undang-undang desain dan perlindungan di bawah hukum merek pada saat memperoleh kekhasan yang cukup.

\section{Penutup}

Peraturan Hukum di Indonesia, Amerika dan Australia secara eksplisit tidak mengatur larangan untuk mendaftarkan bentuk tiga dimensi melalui Undang-Undang Merek dan Undang-Undang Desain Industri/Paten. Tetapi pembatasan pendaftaran bentuk tiga dimensi dapat dilihat melalui syarat bentuk tiga dimensi agar dapat dilindungi berdasarkan UndangUndang Merek berbeda dengan syarat perlindungan Desain Industri/Paten. Pada dasarnya perlindungan terhadap Merek dan Desain Industri memiliki konsep yang berbeda. Merek memberikan perlindungan dengan tujuan bahwa bentuk yang diberikan perlindungan tersebut mampu dibedakan dari produk serupa dan menunjukkan asal barang yang berkaitan dengan kualitas produk itu. Sedangkan Desain Industri bertujuan untuk melindungi suatu desain baru yang dihasilkan melalui proses pemikiran yang mana hasil itu bisa dilihat dalam kesan estetis yang ditampilkan oleh bentuk tersebut.

Pengaturan Bentuk Tiga Dimensi yang Paling Tepat bagi Indonesia dalam studi perbandingan dengan Amerika dan Australia adalah Pertama, penambahan syarat pendaftaran merek tiga dimensi. Untuk mendapatkan perlindungan Trade Dress harus memiliki kekhasan yang melekat (inherently distinctiveness) atau memiliki makna sekunder (secondary meaning). Desain dan konfigurasi produk tidak berhak mendapatkan perlindungan trade dress berdasarkan kekhasan yang melekat saja, tetapi selalu harus memiliki makna sekunder. Sedangkan kemasan produk dapat dapat didaftarkan dengan memiliki kekhasan yang berbeda. Indonesia dapat mengadaptasi pengaturan hukum Amerika dan Australia yang mengatur Merek Tiga Dimensi tidak dapat didaftarkan apabila merupakan bentuk umum yang digunakan dalam perdagangan pada pasar yang relavan. Di Australia merek tiga dimensi tidak dapat didaftarkan jika merupakan bentuk yang umum dalam perdagangan (Shapes which are common to the trade) dan di Amerika trade dress dilindungi apabila memiliki kekhasan yang melekat (inherently distinctiveness). 


\section{Ucapan Terimakasih}

Terima kasih kepada Lembaga Penelitian dan Pengabdian Masyarakat (LPPM) Universitas Internasional Batam (UIB) yang telah mendanai penelitian ini dengan Kontrak No. 028/LPPM/KP-UIB/I/2021 tertanggal 29 Januari 2021. Terima kasih juga dihaturkan kepada Program Magister Hukum Universitas Internasional Batam yang membantu melakukan seleksi dan editing awal sehingga penelitian ini dinyatakan layak untuk dikompetisikan dalam pendanaan penelitian LPPM UIB.

\section{Referensi}

\section{Buku dan Jurnal}

Amirulloh, M., \& Kusmawati, A. P. (2014). Perlindungan Merek terhadap Framing, Meta tag, dan Deep Linking Berdasarkan UU No. 15 Tahun 2001 tentang Merek dan Perbandingannya dengan Regulasi dan Praktik di Amerika Serikat. Padjadjaran Journal of Law, 1(3).

Bafadhal, T. (2018). Perlindungan Hukum terhadap Merek Terkenal di Indonesia. Undang: Jurnal Hukum, 1(1), 21-41.

Benuf, K., \& Azhar, M. (2020). Metodologi Penelitian Hukum sebagai Instrumen Mengurai Permasalahan Hukum Kontemporer. Gema Keadilan, 7(1), 20-33.

Desmayanti, R. (2018). Tinjauan Umum Perlindungan Merek Terkenal Sebagai Daya Pembeda Menurut Prespektif Hukum Di Indonesia. Jurnal Cahaya Keadilan, 6(1), 121.

Disemadi, H. S., \& Mustamin, W. (2020). Pembajakan Merek Dalam Tatanan Hukum Kekayaan Intelektual Di Indonesia. Jurnal Komunikasi Hukum (JKH), 6(1), 83-94.

Faradz, H. (2008). Perlindungan Hak Atas Merek, Jurnal Dinamika Hukum Vol. 8 No. 1 Januari, Fakultas Hukum Universitas Jenderal Soedirman, Surabaya.

Lestanto, B.S. (2011). Konsep Perlindungan Merek Tiga Dimensi (Three-Dimensional Marks): Definisi, Perlindungan dan Penerapa Hukum, Depok: Skripsi Universitas Indonesia.

Mastuti, S. (2018). Efektivitas Prinsip Trade Related Aspects Of Intellectual Property Rights Dan Agreement Technical Barriers To Trade Dalam Pemberian Perlindungan Hukum Terhadap Produk Rokok Indonesia Di Australia Atas Pelaksanaan Asas Ketertiban Umum. Selisik: Jurnal Hukum dan Bisnis, 4(2), 42-63.

Maulana, I.B. (1997). Sukses Bisnis Melalui Merek, Paten dan Hak Cipta, Citra Aditya Bakti, Bandung.

Mayana, R. F. (2017). Perlindungan Merek Non Tradisional Untuk Produk Ekonomi Kreatif Berdasarkan Undang-Undang Nomor 20 Tahun 2016 Tentang Merek, Indikasi Geografis dan Perspektif Perbandingan Hukum. Jurnal Bina Mulia Hukum, 2(1), 26-41. 
Mayana, R.F. (2004). Perlindungan Desain Indsutri dalam Era Perdagangan Bebas, PT Gramedia Widiarsama, Jakarta.

Merges, R.P., et.ll. (2007). Intellectual Property in the New Technological Age (4 ${ }^{\text {th }}$ rev. ed), New York: Wolters Kluwer.

Nadeak, N. A., \& Wauran, I. (2019). Tumpang-Tindih Pengaturan Bentuk Tiga Dimensi Dalam Undang-Undang Merek Dan Undang-Undang Desain Industri. Jurnal Hukum Ius Quia Iustum, 26(1), 21-43.

Nawi, S. (2018). Penelitian Hukum Normatif Versus Penelitian Hukum Empiris, Makassar: PT Umitoha Ukhuwah Grafika.

Pattishall, B.W., \& Hilliard, D.C. (2002). Trademarks and Unfair Competition Fifth Edition, LexiNexis Group.

Prasetya, I. M. D., \& Ariana, I. G. P. (2019). Pengaturan Merek Produk Makanan (Berdasarkanundang-Undang No 20 Tahun 2016 Tentang Merek). Kertha Semaya: Journal Ilmu Hukum, 7(1), 1-14.

Rahmawati, D. (2016). Perlindungan Hukum Atas Indikasi Geografis (Studi Perbandingan Hukum Indonesia Dengan Australia). Kumpulan Jurnal Mahasiswa Fakultas Hukum.

Reidl, P.W. (2019). Understanding Basic Trademark Law : a Primer on Global Trademark Protection, USA: Practising Law Institute.

Saidin, O.K. (2013). Aspek Hukum Hak Kekayaan Intelektual, Jakarta: PT Raja Grafindo.

Standing Committee On The Law Of Trademarks, Industrial Design And Geographical Indications. (2002) Industrial Designs And Their Relation With Works Of Applied Art And Three-Dimensional Marks, Geneva.

Stevens, L., \& Mark, S. (2009). VenderBroek, Protecting and Enforcing Trade Dress, Toronto.

Utrecht, E. (1959). Pengantar dalam Hukum Indonesia, Cetakan keenam, Jakarta: PT.Penerbit Balai Buku Ichtiar.

\section{Peraturan Perundang-undangan}

The Agreement on Trade-Related Aspects of Intellectual Property Rights (TRIPs).

Lahnam Act (the U.S. Trademark Act) 1946

Consolidated Patent Laws "United States Code Title 35 - Patents"

Australian Trade Marks Act 1995

Australian Design Act 2003

Undang-Undang Dasar Negara Republik Indonesia 1945.

Undang-Undang No. 31 Tahun 2000 tentang Desain Industri

Undang-Undang Nomor 20 Tahun 2016 tentang Merek dan Indikasi Geografis. 


\section{World Wide Web}

Amrikasari, R. (2019). Dasar Hukum Perlindungan Merek Non-Tradisional. Available online from: $\quad$ https://www.hukumonline.com/klinik/detail/ulasan/lt5bee57cd0c924/dasarhukum-perlindungan-merek-non-tradisional [accessed 30 October 2019]

Misterovich, E. (2009). Trade Dress Protection. Available online from: https://revisionlegal.com/trademark-law/trade-dress-protection/ [accessed 27 November 2019].

Wikipedia. (2009). Available online from: https://en.wikipedia.org/wiki/Trade dress [accessed 27 November 2019]. 